Літвінова Я.В., Білоног В.В.

Національний технічний університет «Дніпровська політехніка», м. Дніпро, Україна

\title{
УДОСКОНАЛЕННЯ МЕТОДИЧНОГО ПІДХОДУ ДО ПОБУДОВИ РАЦІОНАЛЬНИХ МАРШРУТІВ ПЕРЕВЕЗЕННЯ ВАНТАЖІВ АВТОТРАНСПОРТОМ
}

Дослідження присвячене пошуку нових підходів до підвищення ефективності вантажних перевезень на основі аналізу методів та алгоритмів побудови раціональних схем маршрутів. Для проведення дослідження використано методи порівняння, узагальнення 3 метою визначення особливостей умов реалізації спрощення процесу пошуку раціональних маршрутів перевезення вантажів, а також його вдосконалення, синтезу - при поєднані методу та алгоритму вирішення транспортних задач з розкриттям ролі кожного елемента в системі цілого.

Проаналізовані теоретико-методичні засади провідних науковців в галузі транспорту щодо вирішення існуючих проблем при доставці вантажів клієнтам. Зазначено, що низка проблем при побудові раціональних схем маршрутів пов'язана 3 недосконалими та трудомісткими методами вирішення транспортних задач. Аналіз особливостей вантажних перевезень, як найбільш складного процесу при використанні автомобільного транспорту, дозволив розширити перелік, відмітивши особливість, яка відображає використання неефективних та нераціональних схем маршрутів при перевезенні вантажів. У результаті дослідження встановлено, що в сучасних умовах господарювання рядовому менеджеру, що забезпечує побудову раціональних маршрутів, досить складно забезпечити виконання завдання. Цим визначається доцільність використання двофазної оптимізації при розв'язанні транспортних задач, а саме, суміщень при поєднанні методу «Мітли» та алгоритму вирішення задачі комівояжера при використанні MS Excel. Розглянуто приклад використання зазначеного суміщення для умовного автотранспортного підприємства м. Кривий Ріг. Побудовані та визначені характеристики маршрутів руху вантажного автотранспорту.

Ключові слова: вантажні перевезення, суміщення методу та алгоритму, метод «Мітли», задача комівояжера, маршрутизація.

\section{ВСТУП}

Транспорт, як кровоносна система держави відображає стан економіки в цілому. Розташування країни в центральній частині Європи є досить вигідним 3 точки зору розвитку транспортних систем. Рівень соціально-економічного зростання залежить від функціонування транспортних підприємств $\mathrm{i}$ організації ефективної роботи транспортних засобів зокрема, які беруть участь у створенні готової продукції, забезпечуючи виробництво матеріалами і ресурсами та доставляючи продукцію до споживачів.

Ефективна організація роботи вантажного автотранспорту $\epsilon$ запорукою підвищення ефективності функціонування у багатьох сферах господарювання. Визначення раціонального маршруту для перевезення вантажів, як шлях до підвищення ефективності організації транспортного обслуговування в умовах незадовільного стану доріг, простоїв під час навантаження-розвантаження, хаотичного розташування клієнтів та нестабільності потоку заявок від них, негативно впливає на ведення господарської діяльності підприємств. Саме ефективна маршрутизація дозволить збільшити продуктивність вантажного автотранспорту, задоволеність клієнтів транспортним обслуговуванням та зменшити собівартість цього процесу. Транспортна логістика $є$ одним 3 найбільших центрів витрат, поряд 3 виробництвом, тому будь-якій компанії просто необхідно контролювати i мінімізувати собівартість перевезень.

\section{АНАЛІЗ ЛІТЕРАТУРНИХ ДАНИХ ТА ПОСТАНОВКА ПРОБЛЕМИ}

Під час значних змін у політичному житті держави, відбувається зниження рівня ділової активності, що позначається на попиті на вантажні перевезення. Це значно впливає на коливання обсягів перевезень вантажів, що в свою чергу приведе до відповідних складнощів при визначенні маршрутів руху вантажного автотранспорту. Практика роботи вантажного автотранспорту показує, 
що на ефективність перевезень різних вантажів впливає хаотичне розташування клієнтури, що обслуговується, здебільшого розвізними маршрутами [1].

Економічна ситуація, що погіршується внаслідок нестабільності політичного життя в країні стає все більш непрогнозованою та спонукає автотранспортні підприємства до постійного пошуку економічно-обгрунтованих маршрутів доставки вантажів клієнтам та відповідних транспортних засобів з необхідними характеристиками за для підвищення ефективності перевізного процесу Але для підтримки його високої ефективності ресурси на підприємстві зазвичай обмежені. Перш за все, це відбувається при використанні застарілих основних виробничих фондів, що в свою чергу впливає на зниження продуктивності вантажного автотранспорту та збільшення транспортних витрат вантажовласників. В умовах того, що суб'єкти господарювання та їх ділова активність суттєво залежать від транспорту, необхідно звернути увагу на організацію міських та міжміських вантажних перевезень та на стан автотранспортного комплексу в цілому. Також суттєвим для забезпечення процесу перевезень вантажів є раціональна побудова маршрутної мережі руху транспорту, від ефективності якої залежить низка економічних показників суб'єкта господарювання. На сьогодні, здебільшого, вантажні перевезення виконуються за маятниковими маршрутами, доволі часто 3 порожнім зворотнім пробігом. Незважаючи на низьку ефективність їх використання, вони все одно переважають в міжміських перевезеннях [2].

Перевезення вантажів у міжобласному сполученні є одним 3 найбільш складних з точки зору комерційної роботи видів діяльності автомобільного транспорту та має сім важливих особливостей [3]. По-перше, це виразний взаємозв'язок ринку автотранспортних послуг з товарними ринками, на яких працюють вантажовідправники та вантажоодержувачі. По-друге, перевезення вантажів у міжміському сполученні $\epsilon$ сферою інтенсивної конкуренції. Третьою особливістю $\epsilon$ те, що значна частка перевезень вантажів носить разовий характер. Це наслідок того, що на сьогодні існує багато дрібних перевізників, які з'явились внаслідок існуючої системи оподаткування, що призвела до того, що великі підприємства вимушені ділитись на менші за для переходу на спрощену систему оподаткування. Четверта особливість пов'язана з проблемами завантаження автотранспортних засобів у зворотному напряму. Вона з'являється внаслідок того, що зазвичай на підприємствах, які користуються послугами транспортних компаній, немає власної диспетчерської служби та якщо б і була, то дуже складно швидко знайти вантаж, який необхідно доставити саме в місце навантаження. Тобто швидко повернути автотранспортний засіб без порожнього пробігу досить складно. П'ята особливість це складний документообіг внаслідок взаємодії декількох підприємств, а саме: транспортно-експедиторських, автотранспортних, підприємства - власники терміналів і т.п. Шоста характерна особливість полягає в тому, що автотранспортні та експедиторські підприємства, відправники та одержувачі вантажів знаходяться при виконанні перевезень на значній відстані один від одного. Сьома особливість це різні правові та економічні підгрунтя при комбінованих перевезеннях [2]. На думку авторів у перелік особливостей необхідно ще одну. Вона пов'язана 3 використанням неефективних та нераціональних схем маршрутів, що відбивається на конкурентоспроможності підприємств, які користуються послугами автотранспортних компаній.

Щодо побудови раціональних маршрутів авторами робіт [4-6] зазначено, що вона спонукає до своєчасного виконання доставки вантажів до споживачів та сприяє взаємодії між збутовими, транспортними та іншими організаціями. На сьогодні авторами відмічено, що завдання маршрутизації є більш важливими у порівнянні із завданнями, наприклад завантаження транспортних засобів. Існуючі підходи до складання маршрутів руху транспортних засобів виділяють такі їх різновиди для перевезення вантажів: маятникові, кільцеві, збірно-розбірні, радіальні комбіновані, дільничні [7]. Автором роботи [8] наголошено про те, що вибір маршрутів руху залежить перш за все, від територіального розташування вантажоутворюючих і вантажоприймаючих пунктів, відстані між ними, величини вантажопотоку і вживаного типу рухомого складу. Робота рухомого складу по заздалегідь складених раціональних маршрутах спрощує оперативне планування, забезпечує регулярність перевезень, сприяє підвищенню продуктивності рухомого складу і його ефективності. Авторами також підкреслюється, що при складанні раціональних маршрутів використовуються різноманітні методи від точних до наближених.

Серед закордонних авторів проблема побудови раціональних маршрутів є теж нагальної. Так наприклад в роботі [9] стверджується, що основними способами вирішення проблем неефективності вантажних перевезень $\epsilon$ евристичні методи, тому що вони знаходять найкраще рішення за прийнятний час, на відміну від точних. Вчені в статті [10] представили розбір класичної задачі комівояжера з оглядом різних методів вирішення задачі. Автор наводить різні евристичні алгоритми 
для вирішення симетричної і асиметричної версії проблеми, які легко застосовуються на реальних практичних прикладах. Авторами праці [11] детально аналізується метод Кларка-Райта, за допомогою якого об'єднують маятникові маршрути в кільцеві. Також визначяться ефективність побудови кільцевого маршруту в рамках маршрутизації перевезень.

Аналіз інформаційних ресурсів та наукових робіт дозволив встановити, що велика кількість вчених займалась питаннями побудови раціональних маршрутів при перевезенні вантажів. Вони обгрунтували, що існує тісний зв'язок між ефективністю роботи автотранспортного підприємства та вибором маршруту перевезень вантажів. Багатьма авторами акцентовано увагу на виборі правильного методу прорахунку майбутнього маршруту при доставці вантажів клієнтам. Необхідно зауважити також на тому, що існує багато методів маршрутизації перевезень, більша частина $є$ вельми складними, а їх використання, при обмежених ресурсах транспортної компанії займає значний часовий лаг. Отже існує необхідність розглянути питання щодо удосконалення методичного підходу до побудови раціонального маршруту.

\section{ЦІЛЬ ТА ЗАДАЧІ ДОСЛІДЖЕННЯ}

Обгрунтувати методичний підхід до побудови раціонального маршруту перевезень вантажів в умовах обмежених ресурсів малих автотранспортних компаній.

\section{РЕЗУЛЬТАТИ ДОСЛІДЖЕНЬ}

Загально відомо, що маршрутизація перевезень дозволяє зменшити час виконання кожного маршруту, знизити транспортні витрати на паливо, мінімізувати кількість невиконань замовлень від клієнтів та інше. Однак їі якісне виконання досить часто вимагає значного часу та ресурсів. Так наприклад, як відомо при вирішенні «непідйомної» задачі комівояжера для рядових менеджерів, аналітиків чи вчених, які, як правило, не мають потужних комп'ютерів для моделювання практичних задач оптимізації, зокрема, в MS Excel зручно вирішувати завдання з невеликою кількістю пунктів (до 10). Хоча й для розв'язання цієї ж задачі з невеликою кількістю пунктів об’їзду, тривалість пошуку може сягати до 15-20 хв [12]. Обмеження в 10 пунктів при використанні MS Excel, при обсязі клієнтів, наприклад 30, є запорукою на невірне виконання завдання. Однак, якщо попередньо ранжувати замовлення від клієнтів за певними ознаками та за необхідною кількістю, є можливість якісно вирішити завдання. А практика господарювання на сьогодні вимагає від транспортних компаній якісного обслуговування при значно більшій кількості пунктів розвозу вантажів. Отже існує нагальна потреба у вирішенні сучасних задач з перевезення вантажів при використанні точних методів, але не вимагаючи при цьому значних ресурсів для пошуку раціонального маршруту перевезень. Одним 3 таких способів на погляд авторів статті є використання гібридних технологій, зокрема двофазної оптимізації при розв'язанні транспортних задач, а саме, суміщень при поєднанні методу «Мітли» та алгоритму вирішення задачі комівояжера при використанні MS Excel.

Для обгрунтування зазначеного вище методичного підходу розглянемо наступний приклад. Умовним автотранспортним підприємством укладені договори на виконання автотранспортних послуг з перевезення вантажу. Виконання перевезень здійснюється при використанні маятникових маршрутів долаючи при цьому близько 2863 км (рис. 1). Всього налічується 27 клієнтів, розташованих в радіусі приблизно 150-170 км від м. Кривий Ріг. 


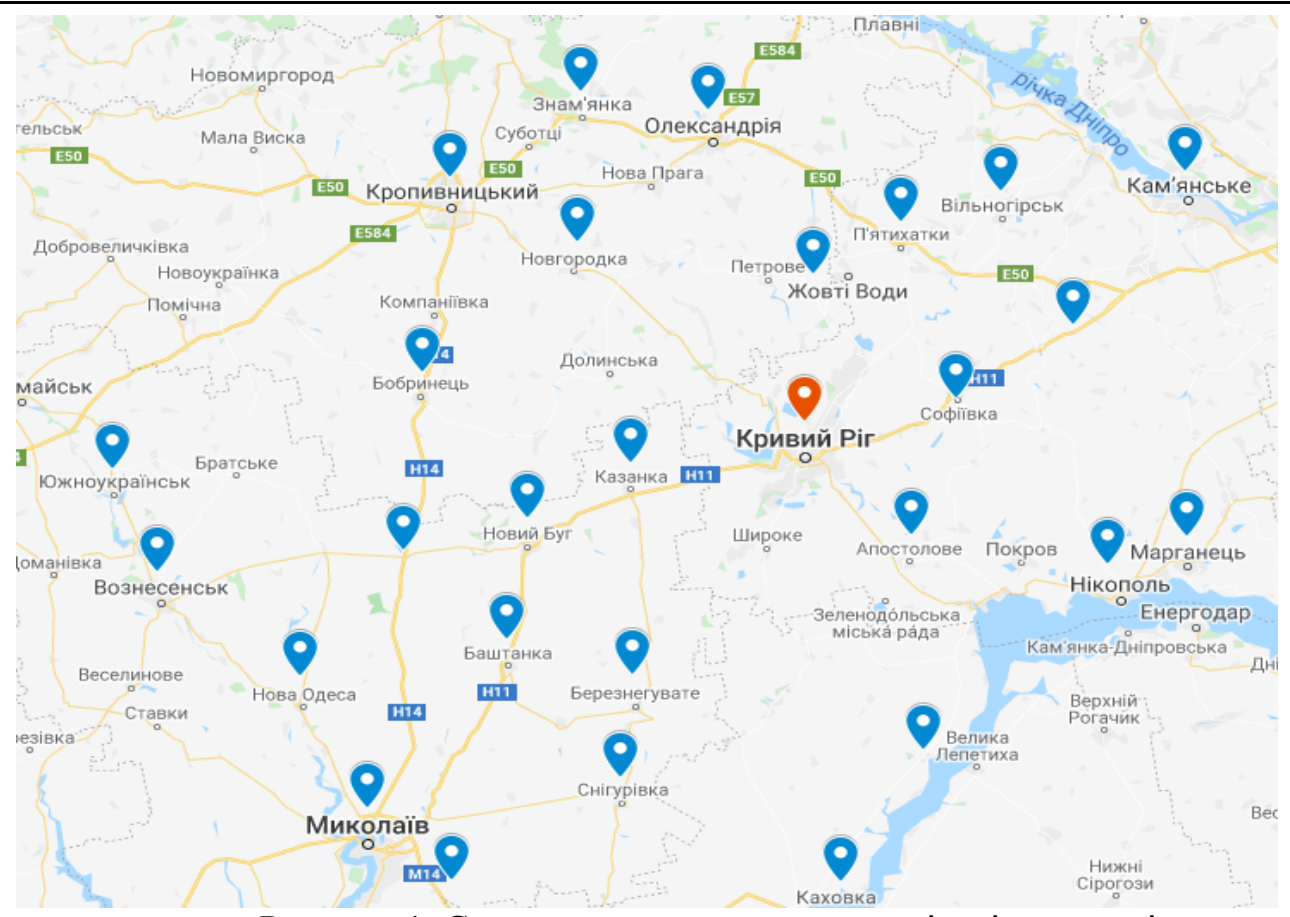

Рисунок 1. Схематичне розташування клієнтів на карті

Під час побудови нових схем маршрутів необхідно враховувати такий фактор як мінімальні витрати, що буде надавати максимальний вплив на перевезення вантажів i, відповідно, можна буде точніше передбачити час проходження всього маршруту. Доставка всієї продукції буде починатися в місці розташування компанії у м. Кривий Ріг. Карта розташування клієнтів представлена на рисунку 1 , де сині маркери - це клієнти компанії, а червоний маркер - це місце розташування умовної компанії, де починається і закінчується маршрут доставки вантажу. Для побудови раціональних схем маршрутів перевезень вантажів необхідно побувати розвізні сектори, які допоможуть сумістити маршрути за територіальною ознакою з урахуванням обмежень. Побудова маршрутів здійснюється за методом «Мітли» $[13,14]$, який реалізується наступним чином. На схемі перевезень будується пряма, яка починається в місті навантаження, а закінчується у випадковому місті розвантаження. Далі пряма обертається за часовою стрілкою чи проти, а клієнт з яким ця пряма дотична, включається в маршрут. На погляд авторів при використанні цього методу обов'язковим є застосування обмежень, які полягають у наступному: перше - використання MS Excel для побудови раціональних маршрутів за допомогою задачі комівояжера, ефективно при кількості пунктів розвозу 10 і менше. Тому першим обмеженням виступить кількість пунктів розвозу вантажів. Друге обмеження полягає в тому, що основним транспортом доставки вантажу будемо вважати автотранспортний засіб 3 вантажопідйомністю 20 тон, а відтак максимальний обсяг вантажу, що перевозиться, не повинен бути більшим. Третє обмеження пов'язане з графіком роботи водія, тобто кількість клієнтів повинна бути такою, щоб при об’ізді всіх транспортний засіб міг повернутись до пункту навантаження до закінчення зміни роботи водія.

Після визначення обмежень та 3 урахуванням кількісних характеристик замовлень продукції клієнтами (табл. 1) були побудовані розвізні сектори (рис. 2).

Таблиця 1. Характеристики замовлень вантажу клієнтами та відстань вантажної їздки при застосуванні маятникових маршрутів

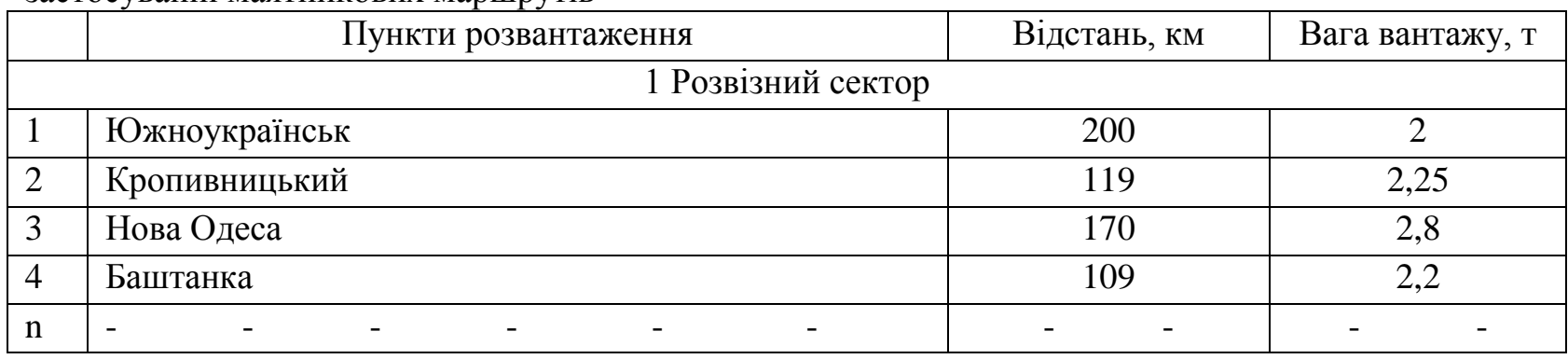




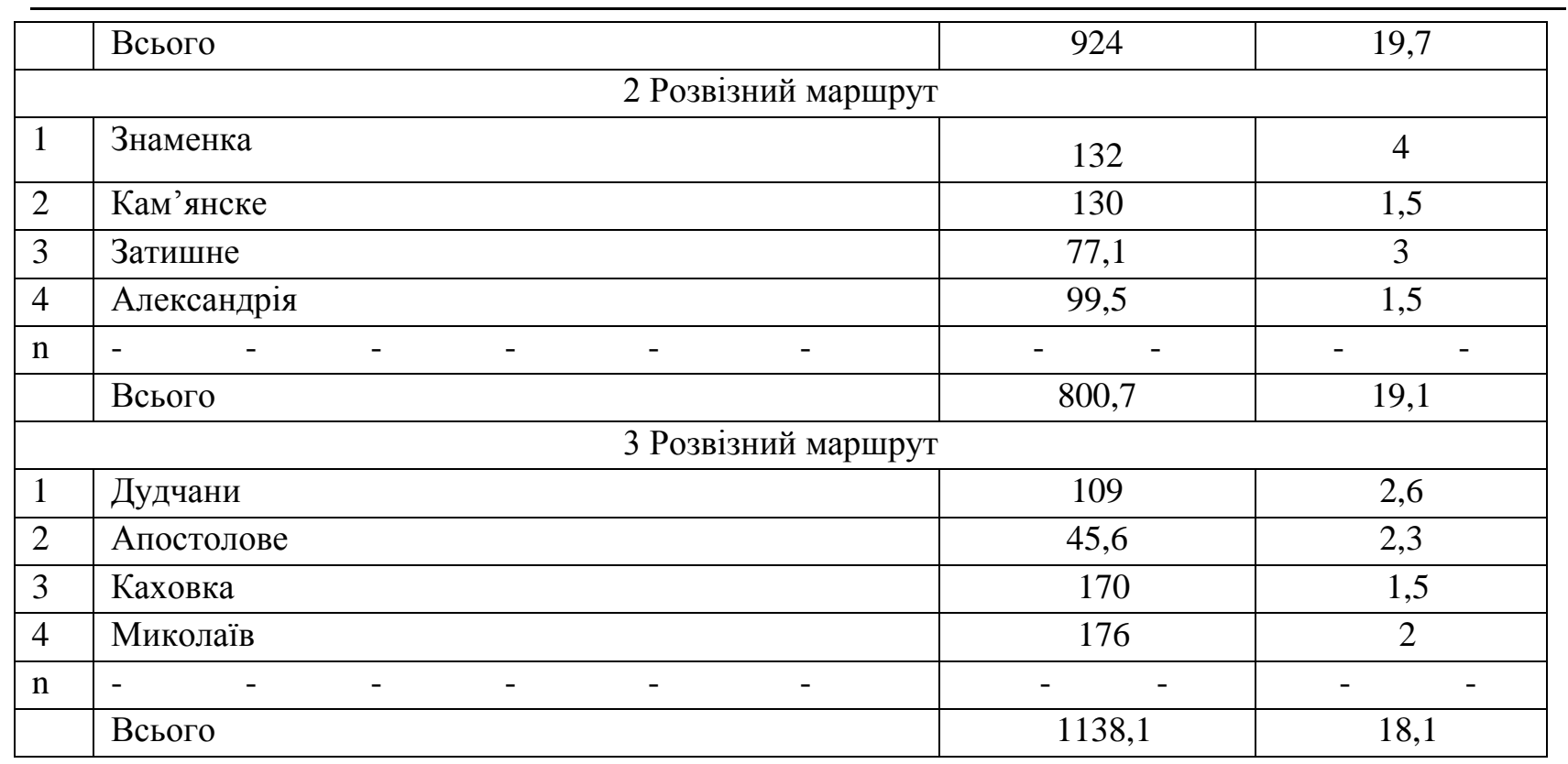

Далі розглянемо побудову раціональних маршрутів при використанні задачі комівояжера, як оптимального варіанту об’їзду пунктів при розгалуженій схемі клієнтів. У цій задачі, маючи матрицю найкоротших відстаней між $n$ пунктами, потрібно побудувати найкоротший розвізний маршрут об'їзду всіх пунктів. Не мають значення обсяги завезення вантажів отримувачам, оскільки вважається, що розвізний маршрут забезпечує можливість задоволення всього попиту. Для виконання такого маршруту доцільно обрати автомобіль оптимальної вантажомісткості, здатний вмістити вантажі відразу всіх отримувачів [15]. Задача комівояжера займає особливе місце у комбінаторній оптимізації та дослідженні операцій. Історично вона була одна з тих задач, які послужили товчком для зв'язку цих напрямів. В теорії обчислювальної складності прийнято розглядати задачі розпізнавання, тобто завдання, в яких відповіддю може бути тільки «Так» або «Ні». На сьогодні задача комівояжера, $\epsilon$ однією з розповсюджених задач оптимізації. 


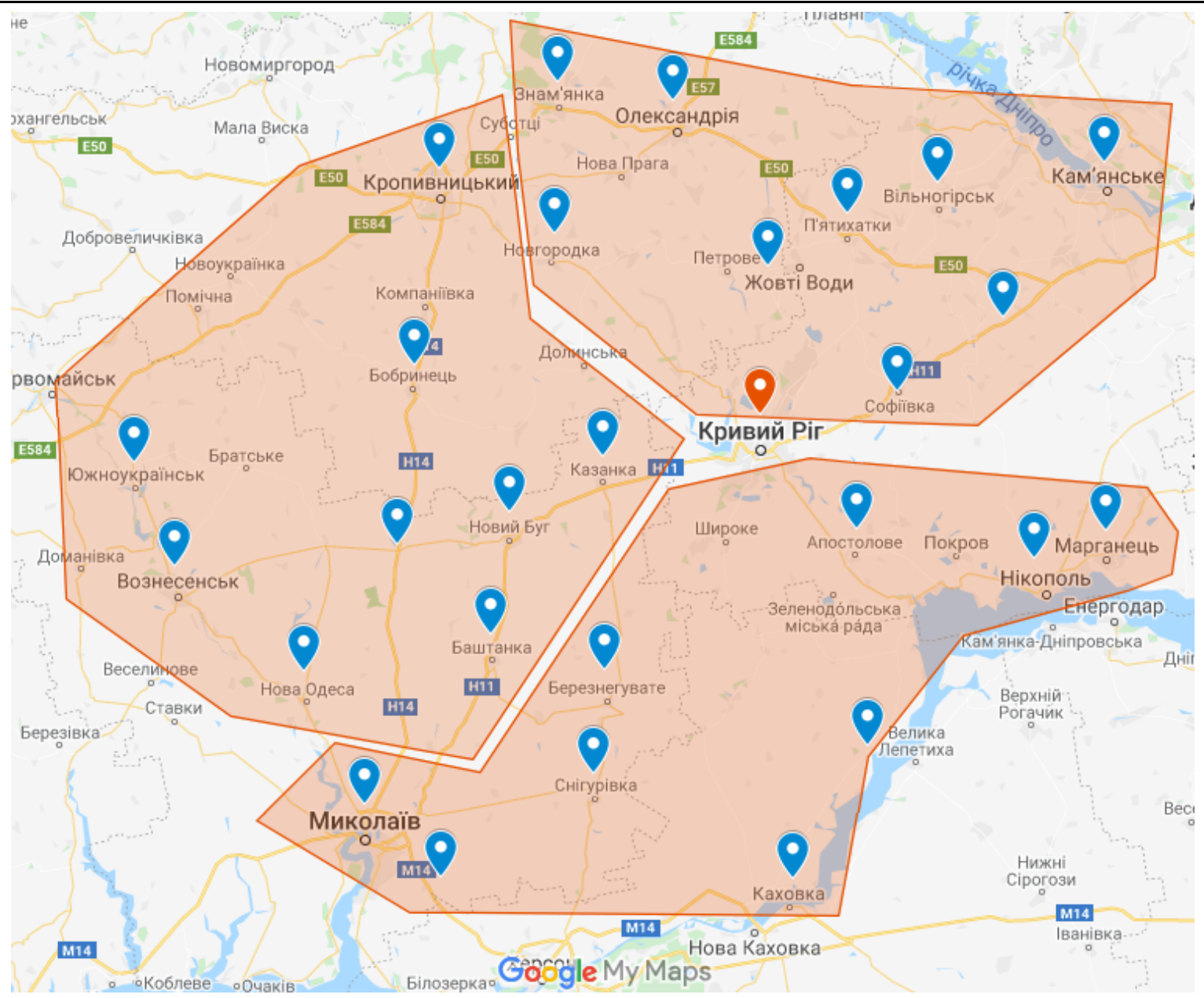

Рисунок 2. Розвізні сектори після використання методу «Мітли»

За допомогою методу «Мітли» визначені розвізні сектори, в рамках яких для першого сектору сформована матриця найкоротших відстаней (рис. 3). На листі MS Excel окрім матриці найкоротших відстаней додаємо матрицю з шуканими невідомими величинами «х», цільову функцію, рядок для додаткових змінних, а також матрицю з обмеженнями по додатковим змінним.

Алгоритм рішення задачі комівояжера в пакеті MS Excel має наступну послідовність: 1. У сформованій матриці найкоротших відстаней, у комірках, які знаходяться на головній діагоналі, прописуємо завідомо велику відстань, для уникнення повторного заїзду в той самий пункт. 2. Формуємо аналогічну, але порожню таблицю, для визначення шуканих невідомих змінних, а отже i оптимального маршруту руху автомобіля. 3. Задаємо цільову функцію, яка розраховується за допомогою вбудованої функції SUMPRODUCT. До третьої таблиці вводимо обмеження по додатковим змінним. Відкриваємо розділ «Дані» і вмикаємо функцію «Пошук рішення». Обираємо комірку з цільовою функцією та зазначаємо напрямок оптимізації «min». В полі «Змінюючи комірки змінних» виділяємо масив другої таблиці та рядку «Додаткові змінні». В полі «У відповідності до обмежень» вводимо наступні обмеження: шукані невідомі змінні повинні бути цілими числами; сума шуканих невідомих змінних по рядках та стовбцях повинні дорівнювати одиниці - умова гарантії того, що тільки один раз автомобіль буде відвідувати кожний пункт на маршруті; значення масиву 3 шуканими обмеженнями по додатковим змінним повинні бути менше або дорівнювати восьми умова того, що при побудові маршруту не з'являться окремі маршрути, які не охоплюють всі пункти. Натискаємо «Знайти рішення» та визначається функція цілі та раціональна послідовність заїзду. Результати для першого розвізного сектору наведено на рисунку 4. 
() Літвінова Я.В., Білоног В.В. 2020

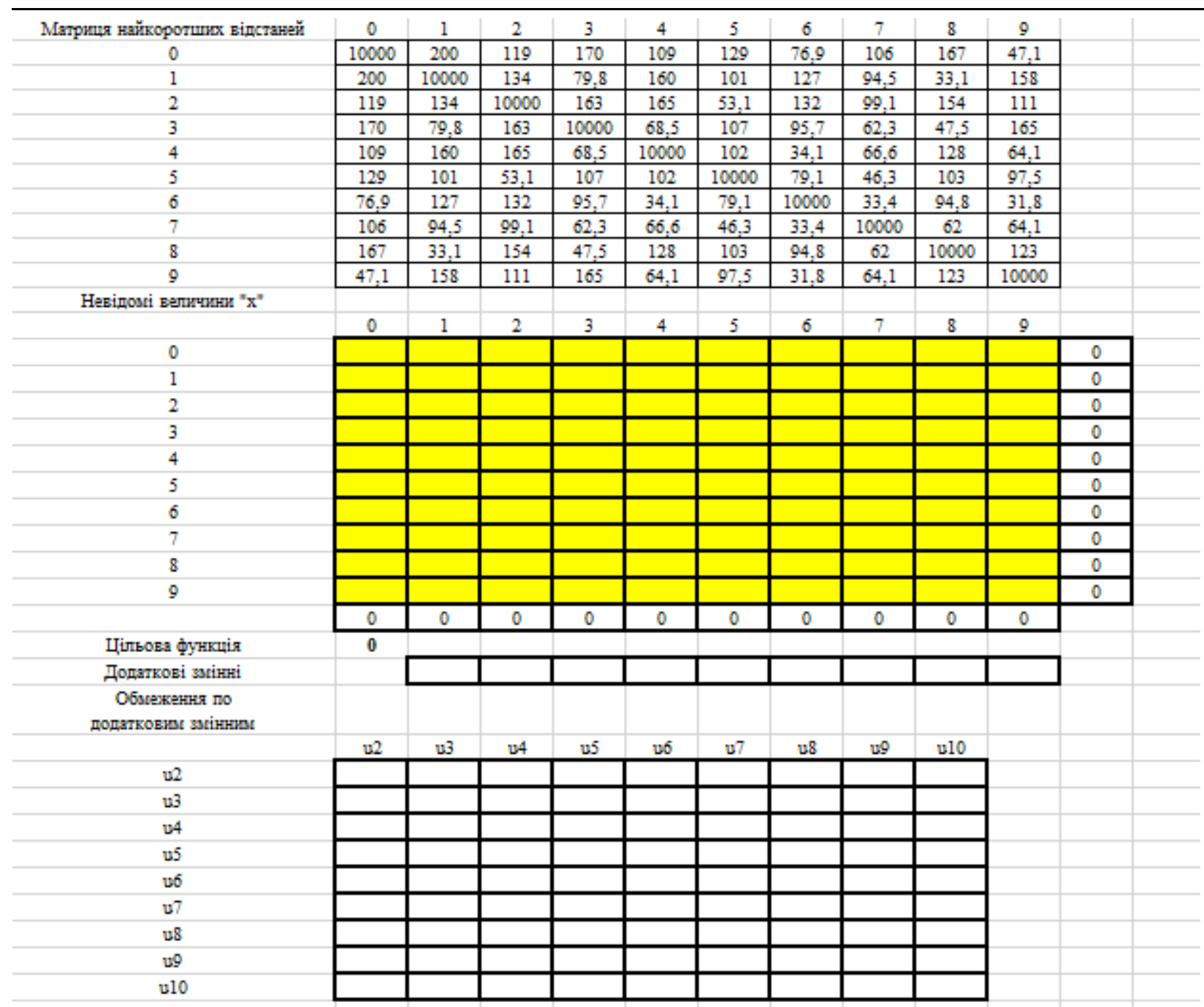

Рисунок 3. Підготовчі операції для рішення задачі комівояжера в пакеті MS Excel для розвізного сектору №1

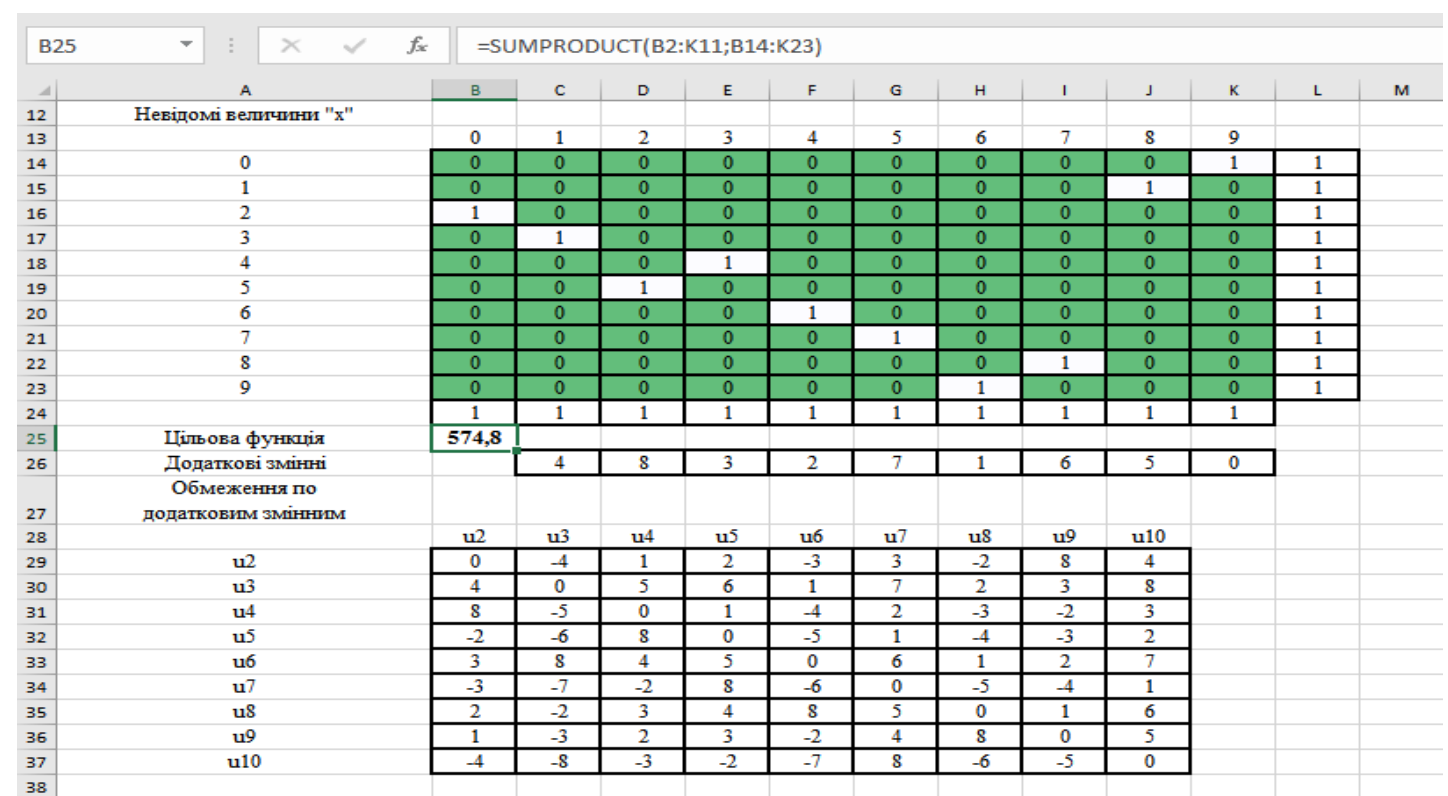

Рисунок 4. Розв’язок задачі комівояжера для розвізного сектору №1

За результатами розрахунків отримуємо наступний маршрут: 0-9-6-4-3-1-8-7-5-2-0. Для розвізного сектору 2 та 3 задача вирішується аналогічно. 


\section{ОБГОВОРЕННЯ РЕЗУЛЬТАТІВ ДОСЛІДЖЕНЬ}

Отже, при суміщенні методу «Мітли» та алгоритму вирішення задачі комівояжера у середовищі MS Excel отримані нові розвізні маршрути, використання яких дозволяє зменшити собівартість перевізного процесу та підвищити якість обслуговування замовників доставки вантажів. Проведені розрахунки дозволяють отримати наступну довжину для маршрутів, відповідно для першого - 527,7 км, для другого - 457 км, третього - 669,8 км. Виходячи з наведених характеристик визначено, що для об'їзду всіх клієнтів необхідно подолати сумарних пробіг 1743 км. У порівнянні з пробігом при використанні маятникових схем руху вантажного автотранспорту він $є$ значно меншим (пробіг при існуючій схемі - 2863 км).

Ефективність використання зазначеного підходу відбивається у значному спрощенні процесу вирішення зазвичай «непідйомної» задачі комівояжера при обмежених ресурсах автотранспортного підприємства, що дозволяє вчасно реагувати на попит у перевезеннях вантажів, бути гнучким під час його коливання та конкурентоспроможнім серед автотранспортних підприємств, що здійснюють вантажні перевезення на великі відстані у міжобласному сполученні.

\section{ВИСНОВКИ}

Визначено, що для якісного проведення маршрутизації при перевезенні вантажів витрачаються значні ресурси. Особливо це стосується малих автотранспортних підприємств де для рядових менеджерів при вирішенні «непідйомної» задачі комівояжера та використанні при цьому непотужної комп'ютерної техніки $є$ вельми складною задачею. Враховуючи складність та трудомісткість знаходження раціональної схеми маршруту руху вантажних автомобілів, де кількість пунктів розвозу значно перевищує оптимальну межу та, відповідно, витрачається значний час на переробку вихідних даних, запропоновано використовувати двофазну оптимізацію для розв'язання транспортних задач, а саме, суміщень при поєднанні методу «Мітли» та алгоритму вирішення задачі комівояжера при використанні MS Excel. Це дозволить значно зменшити трудомісткість процесу проведення маршрутизації вантажних перевезень та підвищить їх якість.

Використання методу «Мітли» дозволяє окреслити розвізні сектори виходячи з трьох обмежень. Перше пов'язано 3 використання MS Excel де ефективно можна вирішити задачу комівояжера 3 кількістю пунктів до 10. Друге обмеження полягає в тому, що для доставки вантажу використовується автотранспортний засіб з вантажопідйомністю 20 тон Третє обмеження пов'язане з графіком роботи водія. Встановлено, що суміщення методу «Мітли» та алгоритму вирішення задачі комівояжера, використовуючи MS Excel для пошуку раціонального маршруту, дозволить побудувати розвізні маршрути зі значною кількістю пунктів розвозу при попередньому ранжуванні на розвізні сектори у відповідності до обмежень. Застосування розвізних маршрутів дозволяє скоротити пробіг в приведеному умовному випадку при доставці вантажів на $39 \%$.

\section{ПЕРЕЛІК ДЖЕРЕЛ ПОСИЛАННЯ}

1. Нагорный Е.В.,. Музылев Д.А. Стратегия формирования городских развозочных маршрутов на оперативный период с учетом неравномерности распределения спроса на специфические грузы. Восточно Европейский журнал передовых технологий. 2009. 6/4 (42). С. $27-30$.

2. Шуліка, О.О. Формування процесу доставки тарно-штучних вантажів автомобільним транспортом у міжміському сполученні : автореф. дис. ... канд. техн. наук : 05.22.01. Харків, 2017. 20 с.

3. Нагорний Є.В., Шраменко Н.Ю. Комерційна робота на транспорті: підручник. Харків : ХНАДУ, 2010. 324 с.

4. Нагорний С.В., Наумов В.С., Шуліка О.О. Формування варіантів технології доставки тарноштучних вантажів автомобільним транспортом у міжміському сполученні. Автомоб. трансn. 2013. № 32. C. 61-66.

5. Алькема В.Г. Маршрутизації доставки вантажів автомобільним транспортом. Вісник Національного транспортного університету. 2011. № 24(2). С. 108-113. Режим доступу: http://nbuv.gov.ua/UJRN/Vntu_2011_24\%282\%29_27

6. Нагорний С.В., Шраменко Н.Ю. Аналіз критеріїв ефективності функціонування логістичних систем при доставці вантажів. Наукові нотатки: міжвузівський збірник. Луцьк: ЛНТУ, 2010. № 28. с. 353-357.

7. Горев А.Э. Грузовые автомобильные перевозки: учеб.пособие для студ. высш. учеб. Заведений. М.: Издательский центр «Академия», 2008. 288 с. 
8. Томляк С.I., Поляков А.П. Шляхи підвищення ефективності перевезення вантажів автомобільним транспортом. // Наукові нотатки: міжвуз. наук. зб. Луцьк: ЛНТУ, 2014. - Вип. 46. - с. 529-537. Режим доступу: http://nbuv.gov.ua/UJRN/Nn_2014_46_85

9. Toth, Paolo The vehicle routing problem / Paolo Toth, Daniele Vigo - Society for Industrial and Applied Mathematics, 2002. $367 \mathrm{p}$.

10. Laporte, G. A Concise Guide to the Traveling Salesman Problem. JSTOR. URL: http://www.jstor.org.ezproxy.gsom.spbu.ru:2048/stable/pdf/40540226.pdf?_=1460820285494

11. W.E. Hardy, Vehicle routing efficiency - A comparison of districting analysis and the ClarkeWright method, Am J Agric Econ 62 (1980), 534- 536.

12. Додонов О.Г., Кузьмичов А.І. Оптимізаційні моделі еволюційного програмування в Excel: розв'язання задачі комівояжера з обмеженнями alldifferent. Реєстрація, зберігання і обробка даних. 2011. T. 13, № 3. C. 3-16.

13. Akhand, M. A. H. \& Jannat, Zahrul \& Sultana, T. \& Rahman, M. M.. (2017). Solving capacitated vehicle routing problem using variant sweep and swarm intelligence. Journal of Applied Science and Engineering. 20. 511-524. 10.6180/jase.2017.20.4.13.

14. Shankar, R.B.S., Reddy, K.D., Venkataramaiah, P.: Solution to a capacitated vehicle routing problem using heuristics and firefly algorithm. International Journal of Applied Engineering Research 13(21) (2018) $15247-15254$

15. Лащених, О.А., Кузькін О.Ф. Методи і моделі оптимізації транспортних процесів і систем: навч. посібник. Запоріжжя: ЗНТУ, 2006. 434 с

\section{REFERENCES}

1. Nagorniy, Ye.V., Muzylev, D.A. (2009). Strategiya formirovaniya gorodskih razvozochnyh marshrutov na operativnyj period s uchetom neravnomernosti raspredeleniya sprosa na specificheskie gruzy // Vostochno-evropejskij zhurnal peredovyh tehnologij. № 6/4(42). 27-30.

2. Shulika, O.O. (2017). Formation of packaged cargo delivery process in the intercity by road transport. Extended abstract of candidate's thesis. Kharkov, [in Ukrainian].

3. Nagorniy, Ye.V., Shramenko, N.Yu. (2010). Commercial work on transport. Kharkiv National Automobile and Highway University, 324.

4. Nagornij, Ye.V., Naumov, V.S., \& Shulika, O.O. (2013). Formuvannja variantiv tehnologiï dostavki tarno-shtuchnih vantazhiv avtomobil'nim transportom u mizhmis'komu spoluchenni. Avtomobil'nyj transport. 32. 61-66.

5. Alkema, V.G. (2011). Marshrutyzatsiya dostavky vantazhivky avtomobil'nym transportom. The National Transport University Bulletin. 24(2). C. 108-113

6. Nagornij, Ye.V., Shramenko, N.Yu. (2010). Analiz kriteriyiv efektivnosti funkcionuvannya logistichnih sistem pri dostavci vantazhiv. Naukovi notatki: mizhvuzivskij zbirnik. 28. 353-357.

7. Gorev, A.E. Gruzovyie avtomobilnyie perevozki [Freight automobile transportation]. Moscow, Publishing center "Academy", 2008. $288 \mathrm{p}$

8. Tomlyak, S.I., Polyakov, A.P. (2014). SHlyahi pidvischennya efektivnosti perevezennya vantajiv avtomobilnim transportom. Naukovi notatki: mijvuz. nauk. zb. Lutsk: LNTU, 2014. 46. 529-537.

9. Toth, Paolo The vehicle routing problem / Paolo Toth, Daniele Vigo - Society for Industrial and Applied Mathematics, 2002. 367 p.

10. Laporte, G.A Concise Guide to the Traveling Salesman Problem. JSTOR. URL: http://www.jstor.org.ezproxy.gsom.spbu.ru:2048/stable/pdf/40540226.pdf?_=1460820285494

11. W.E. Hardy, Vehicle routing efficiency-A comparison of districting analysis and the ClarkeWright method, Am J Agric Econ 62 (1980), 534- 536.

12. Dodonov, O.G., Kuzmychov, A.I. (2011). Optymizatsiyni modeli evolyutsionuyut' prohramu v Excel: rozshyrennya zadach komisiyi z obmezhennyam alldifferent / Data recording, storage \& processing. T. 13, № 3. C. 3-16.

13. Akhand, M. A. H. \& Jannat, Zahrul \& Sultana, T. \& Rahman, M. M.. (2017). Solving capacitated vehicle routing problem using variant sweep and swarm intelligence. Journal of Applied Science and Engineering. 20. 511-524. 10.6180/jase.2017.20.4.13.

14. Shankar, R.B.S., Reddy, K.D., Venkataramaiah, P.: Solution to a capacitated vehicle routing problem using heuristics and firefly algorithm. International Journal of Applied Engineering Research 13(21) (2018), $15247-15254$ 
15. Lashchenykh, O.A., Kuz'kin, O.F. (2006). Methods and models of optimization of transport processes and systems. Zaporozhye: ZNTU, 434.

Ya. Litvinova, $V$. Bilonog. The methodical approach improvement to the designing of rational routes for freight transit by automobile trasportation

The research is devoted to the search of new approaches to improve the efficiency of freight transportation based on the analysis of methods and algorithms for rational routing schemes designing. Methods of comparison and generalization were used to determine the peculiarities of the simplification of finding rational routes of cargo transportation process, as well as its improvement, synthesis - by combining the method and algorithm of solving transport problems with each element role exposure in the system.

Theoretical and methodological principles of leading scientists in the field of transport as for solving existing problems in the goods delivery to customers are analyzed. It is noted that a number of problems in the rational route schemes designing are associated with imperfect and time-consuming methods of transport problems solving. Analysis of the peculiarities of freight transportation as the most complex process in the road transport use, allowed expanding the list, noting a feature that reflects the use of inefficient and irrational routing schemes in the goods transportation. As a result of research it is established that under modern conditions of managing it is difficult enough to provide task performance to an ordinary manager providing designing of rational routes. This determines the feasibility of using two-phase optimization in solving transport problems, namely, combinations in the joining the "Sweep algorithm" and the algorithm for solving the problem of salesman when using MS Excel. The example of the specified combination usage of the conditional motor transport enterprise of Kryvyi Rig is examined. The characteristics of freight traffic routes are designed and determined.

Keywords: freight transportation, combination of method and algorithm, "sweep algorithm", traveling salesman problem, routing.

ЛІТВІНОВА Яна Володимирівна, кандидат технічних наук, доцент кафедри «Управління на транспорті», Національний технічний університет «Дніпровська політехніка», e-mail: litvinovayana87@gmail.com, https://orcid.org/0000-0003-2806-4076

БІЛОНОГ Владислав Вікторович, студент кафедри «Управління на транспорті», Національний технічний університет «Дніпровська політехніка», e-mail: vicradrt@gmail.com

Yana LITVINOVA, Candidate of Technical Science, associate professor of Transport Management Department, Dnipro University of Technology, e-mail: litvinovayana87@ gmail.com, https://orcid.org/0000$\underline{0003-2806-4076}$

Vladyslav BILONOG, student of the Department of Transport Management, Dnipro University of Technology, e-mail: vicradrt@gmail.com

DOI: 10.36910/automash.v2i15.392 